\title{
Collective Intelligence Algorithms in Pedagogical Practice
}

\author{
Mykhailo G. Koliada* and Tatyana I. Bugayova \\ Donetsk National University \\ Donetsk, Ukraine
}

Received 01.03.2019, received in revised form 12.01.2021, accepted 09.03.2021

\begin{abstract}
The article considers the ideas of using artificial intelligence algorithms in pedagogics. It presents the methodology of the so-called collective pedagogical megasystem. The introduction of such an ephemeral construct is necessary only to understand the collective pedagogical intelligence system, formulate it in a model, find out its operation patterns and the laws it obeys. It would contribute to predicting pedagogical processes and phenomena and formulating new laws.

The objective of the article is to demonstrate the application of collective intelligence algorithms in pedagogical practice for effective didactic decision-making. The matter is that in a real educational process, besides the well-known set of pedagogical conditions, there are some random and unpredictable reasons and factors that are hard to foresee or anticipate. Due to their stochastic nature, they occur spontaneously. These single reasons make a minor impact on the teaching methods selection, but in aggregate their influence gets so strong that they can upturn some prognostic conclusions. The problem also focuses on identifying the factors that would ensure the highest efficiency and productivity of studies among the known (expected) and random (unexpected) reasons. For these purposes, the most suitable algorithm for the selection training methods is the so-called ant algorithm which, on the one hand, considers the randomness of the influence parameters, and on the other, ensures steady and high productivity.

A certain example was selected to demonstrate the process of applying the ant algorithm to reveal the best hierarchy of the pedagogical conditions (factors) that determines the optimum choice of the training method.

The authors conclude that human intelligence is distributed and integrated at the same time, and the application of collective intelligence algorithms in pedagogical practice can yield some effective didactic decisions.
\end{abstract}

Keywords: collective mind, collective intelligence, ant colony algorithm, self-organization, selection of teaching method.

Research area: pedagogy.

Citation: Koliada, M.G., Bugayova, T.I. (2021). Collective intelligence algorithms in pedagogical practice. J. Sib. Fed. Univ. Humanit. Soc. Sci., 14(3), 327-340. DOI: 10.17516/1997-1370-0724.

(C) Siberian Federal University. All rights reserved

* Corresponding author E-mail address: kolyada_mihail@mail.ru, bugaeva_tatyana@mail.ru

ORCID: 0000-0001-6206-4526 (Koliada); 0000-0003-1926-1633 (Bugayova) 


\title{
Применение алгоритмов коллективного разума в педагогической практике
}

\author{
М.Г. Коляда, Т.И. Бугаева \\ Донеикий национальный университет \\ Украина, Донеик
}

\begin{abstract}
Аннотация. В статье рассмотрены идеи использования алгоритмов искусственного интеллекта в педагогике. Представлена методология существования и функционирования так называемой коллективной педагогической мегасистемы. Идея ввода такого эфемерного образования нужна лишь для того, чтобы модельно и доступно понять саму систему коллективного педагогического интеллекта, опосредованно разобраться, как она работает, какие законы в ней действуют. На ее основе можно прогнозировать педагогические процессы и явления, находить новые закономерности.
\end{abstract}

Цель статьи - показать применение алгоритмов коллективного разума в педагогической практике для эффективного принятия дидактических решений. Дело в том, что в реальном образовательном процессе, кроме известного множества педагогических условий, действуют и случайные, наперед неизвестные причины и факторы, которые трудно предвидеть и предусмотреть заранее. Они возникают спонтанно и чаще всего имеют стохастический характер. Эти «поодиночные» причины несущественно влияют на результаты прогноза выбора методов обучения, но в совокупности их влияние становится столь значимым, что они коренным образом могут менять прогностические выводы. Задача состоит в том, чтобы в конкретных условиях из множества известных (предусмотренных) и случайных (неожиданных) причин выделить именно те факторы, которые обеспечивали бы наивысшую продуктивность и результативность занятия. Для решения этой задачи наиболее подходящим алгоритмом в реализации отбора методов обучения является так называемый муравьиный алгоритм, который, с одной стороны, учитывает вероятностный характер меняющихся параметров воздействия, а с другой устойчиво дает высокую результативность своего применения.

На конкретном примере показан процесс реализации применения муравьиного алгоритма для выявления наилучшей иерархии педагогических условий (факторов), которые определяют оптимальный выбор метода обучения.

Обоснован вывод, что человеческий интеллект становится одновременно распределенным и объединенным и что, применяя алгоритмы коллективного разума в педагогической практике, можно получать эффективные дидактические решения.

Ключевые слова: коллективный разум, коллективный интеллект, муравьиный алгоритм, самоорганизация, выбор метода обучения.

Научная специальность: 13.00.00 - педагогические науки. 


\section{Introduction}

History of collective intelligence development and research problems

The expressions of collective intelligence or swarm intelligence assume the retrieval of new knowledge from the combined preferences of a group of individuals (agents) and the feasibility of a wise collective. In the modern interpretation, the term was introduced by Gerardo Beni and Wang Jin in 1989, in the context of creating a system of cellular robots (automatons). The British scientist Francis Galton was one of the first to notice that people in a group had a remarkable collective intelligence and were able to produce more perceptive solutions than those generated by the most intelligent individuals. In 1906, he carried out a series of experiments and concluded that «Groups do not need to be dominated by exceptionally intelligent people in order to be smart. Even if most of the people within a group are not especially well-informed or rational, it can still reach a collectively wise decision» (Surowiecki, 2007: 12).

Most alive organisms are also capable of making collective reasonable decisions. It is not uncommon; in fact, it has been well-known to the biologists that in a multicellular organism the coordination of cell behaviour is provided by a specific centralized control system (nervous and humoral systems). But it is still a mystery when a group of separate independent organisms (usually referred as agents), such as fish, ants, or bees, that do not have a centralized control system whatsoever, manifest a sort of collective management. It is incomprehensible how they coordinate their actions, where the management information is stored, how the reasonable decision-making mechanisms are activated.

It has been found out that there is a different, still undescribed method that works here. However, for some living creatures, the general collective intelligence «mechanism» has been partially unravelled, and it operates with the help of the so-called quorum sensing.

This phenomenon has been most accurately studied in unicellular organisms. They have a concerted group behaviour, which is normally based on an original chemical vote. For example, all the bacteria in the population egest a signal agent; when the concentration of this agent in the environment reaches a certain threshold value, all the cells change their behaviour (e. g., begin to attract to each other and assemble in large accumulations). Some biological experiments have shown that the behaviour of gregarious species (fish, ants, bees, saiga antelopes, deer, wolves, etc.) is organized based on the actions of other pack members (Ushakov (ed.), 2004; Liusin (ed.), 2004). They get information from each other in the matters of finding food, reproduction etc. and receive a mutual benefit.

We can assume that as humans are creatures that have the ability to think, they certainly have the ability to make collective unconscious (without awareness, sensation, or cognition of individuals) reasonable high-level decisions. In general, many facts prove that humans do have unconscious collective intelligence. For example, the American scientists from Carnegie Mellon University (Pittsburgh, Pennsylvania), Union College (Schenectady, NY) and Massachusetts Institute of Technology have managed not only to measure the collective intelligence (one of the research member laboratories was the Center for Collective Intelligence), but also to justify the statement that the collective intelligence is similar to the «client-server» system (like in the Internet) (Smoll, Vorgan, 2011; Tapskott, 1999; Tarasenko, 2000; Hardaker, 2010; Heylighen, 1996; Wellman, 2001), so, it can be claimed that the existence of distributed group intelligence has been thoroughly proved just as the existence of individual intelligence (Slavina, 2014: 270; Woolley, Fuchs, 2001). A group of scientists headed by A. Woolley declared that the collective intelligence phenomenon only secondarily depends on the individual intellectual abilities of the group members, but primarily it depends on the "social sensitivity» as well as the absence of a pronounced team leader, dominating the group work process (Woolley et al., 2001).

There are four conditions that characterize wise collective intelligence (Surowiecki, 2007: 27): 1) diversity of opinion (every person 
should have some private information, even if it's just an eccentric interpretation of the known facts); 2) independence (people's opinions are not determined by the opinions of those around them); 3) decentralization (people are able to specialize and draw on local knowledge) and 4) aggregation (some mechanism exists for turning private judgments into a collective decision). If a group satisfies those conditions, its judgment is likely to be accurate. It occurs when we speak of a mathematical truism. If you ask a large enough group of diverse, independent people to estimate a probability, and then average those estimates, the errors each of them makes in coming up with an answer will cancel themselves out.

According to D. Surowiecki (Surowiecki, 2007: 16), collective intelligence can be applied to solve a great number of problems, namely: 1) cognition problems, when you need to solve specific problems related to the behaviour of human activities; 2) coordination problems related to the coordination of group members according to their interests; 3) cooperation problems related with the necessity to coordinate actions of group members. There is a question, whether it is possible to apply collective intelligence ideas in the field of education and pedagogy.

In pedagogy, we face a great number of problems that may be solved through the implementation of collective intelligence. The ideas of collective intelligence may also be applied to solve optimizing multifactorial matters. Unfortunately, the theoretical and practical aspects of this problem are still understudied: such important issues as the effective application of mathematical models in pedagogical decisionmaking by using the collective intelligence algorithms are still underestimated by researchers.

However, it is necessary to consider the practical importance of using grounded algorithms for the implementation of collective intelligence ideas. The lack of theoretical justification and practical implementation of these algorithms in pedagogy and education management motivated the writing of the present article titled «Collective Intelligence algorithms in pedagogical practice».
This research is relevant not only for the researchers dealing with problems of implementing computational methods in the studies of pedagogical processes and phenomena but also for ordinary teachers in search of evidence-based ways of making productive pedagogical decisions. We hope that this paper will provide a powerful theoretical and practical tool in their professional activities.

The objective of the article is to demonstrate the advantages of applying collective intelligence algorithms in teaching practice for efficient pedagogical decision-making and the identification of productive educational methods. Among the main issues covered by the research, there are: 1) methodological foundation for the existence and functioning of the Collective pedagogical megasystem; 2) a certain example that shows the process of implementing the ant colony algorithm for the hierarchy of conditions (factors) to select the right teaching method.

\section{Research methodology}

Let us try to justify the education evolution concept and the idea of a collective pedagogical super organism as a collective pedagogical megasystem.

Such an ephemeral structure as a collective pedagogical super organism is only needed as a model or a tool to understand the very system of collective pedagogical intelligence. We had to introduce this hypothetical concept to explain many processes and phenomena in training and education that sometimes feel appear mysterious. It is not clear how they are controlled: whether from the outside, by some kind of a global centre (Subbotskii, 2007), or by a so-called universal mind (Aronson, 1998; Bard \& Zoderkvist, 2005). In fact, an ordinary person is incapable of understanding or look at this collective pedagogical superorganism from outside, of observing it as he observes an existing animal or human organism. But every person involved in the teaching and learning process can indirectly figure out how it functions, what kind of laws it is regulated by, how the protection and safety systems work (similar to the immune system designed to control all kinds of external threats and to provide pro- 
tection against the internal destructions for the normal functioning of the living organism). Perhaps, it is associated more with the expansion rather than the restriction of individual opportunities, democracy and decentralization in pedagogy. Education experience shows that the implementation of differentiation mechanisms into pedagogical practices provides a wider choice of educational forms and methods to all participants of the process (Reingold, 2006; Hebb, 1949).

As we know, in the physical world (in terms of physics), the reduction of friction always increases motion. It is clear that in pedagogy, additional integration mechanism involves new limitations, but they are rather aimed at moderating the excessive freedom of teaching and educational innovations. Thus, this is more a matter of protecting the collective pedagogical superorganism from breaking down than of limiting the freedom and ambitions of ordinary learners and teachers. They have been incorporated in the collective pedagogical super organism of the didactic idea not only in terms of the customary exchange of training and educational information but also from the position of a necessity to use some advanced pedagogical experience, new educational technologies and systems. Sometimes they completely depend on the settings and the community directives issued in the educational management sphere, as well as the goals and objectives of the established educational approaches.

The system of the collective pedagogical superorganism supports itself and takes care of its own growth and development, while the ambient social system is perceived as a possible cause of an internal functioning failure. All the parts of the superorganism are functionally autonomous, but at the same time, closely integrated into the network of a global social system, they interact with each other due to their ability to self-organization. The collective pedagogical super organism system does not have clear spatial boundaries, although internally it is organizationally closed, i. e. it has an internal substructure (Janis, 1972; Salminen, 2012). The global social system (Reingold, 2006) is only the source of educational information and energy (to im- plement creative ideas, to seek the best pedagogical efficiency and the highest productivity etc.). According to the second law of thermodynamics, to maintain equilibrium, it needs to export its entropy or energy (similar to heat) into the global social system. This implies that the information and energy flow in the educational system with a low level of entropy, and flow out after the high entropy level transformations. The entropy dissipated or absorbed by the collective pedagogical megasystem is required to ensure the educational processes and phenomena. It also maintains the operation of the system (Slavina (ed.), 2014).

Hypothetically, the process of improvement (training) of the collective pedagogical megasystem is based on a principle similar to D. Hebb rule (Slavina (ed.), 2014) formulated for the living neural networks: if neurons are activated simultaneously for a predetermined time, the connection between them intensifies (similarly to what happens during the chemical «vote»). Drawing an analogy with a living neural network, it becomes obvious that accumulated knowledge or experience is equivalent to neurons, and the process of using (assimilating) them by learners and teachers for a certain time is the equivalent of activation. The more of them make efforts to implement this knowledge, the stronger is the link between them. In other words, pedagogical knowledge and experience should be used and implemented in actual pedagogical practice to increase the global importance of the intelligent pedagogical super organism. This self-regulation by means of self-study gradually leads to the change and improvement of the entire collective pedagogical megasystem. Fragmental knowledge is based on versatile collective knowledge, skills and experience, that are not always directly related to the pedagogical material. Eventually, it is transformed into a connected associative reasonable structure, which can be easily compared with an alive neural network in the human brain, but with a wider structure. Thus decentralization of knowledge is extremely important. However, its initial centralization forms a negative character. The main advantage of centralization is the possibility to frame its management system into a clear physical 
form to analyze and improve it more efficiently. But decentralization does not result in a collective of equal people, where they could not find a place for personal development and initiative in making educational decisions. It is important to maintain a variety of strategies used inside the collective pedagogical megasystem. The decisions should also be independent, as they influence the choice of optimal ways to implement knowledge. Diversity and independence in a megasystem are important because the best collective decisions «are the product of disagreement and contest, not consensus or compromise» (Surowiecki, 2007: 18).

\section{Theoretical basis for the selection of teaching methods}

The selection of teaching methods by a teacher is associated with a variety of causes and factors, both objective and subjective. Choosing a teaching method, the teacher is limited by certain interdependent conditions.

The educators and researchers often include the goals and objectives of the class to the main reasons and factors. In particular, they dictate the main group of methods required to fulfil the objectives and goals of the class. After the methods have been selected, the teacher determines the ways to implement them.

But are the optimal teaching methods chosen in actual teaching practice?

Usually the teacher chooses a pedagogical approach intuitively, which is not always efficient. Theoretically, the teacher should select the most appropriate methods and techniques from the variety of the known and proven ones. But in actual teaching practice, except for the well-known methods and conditions, there arise some random unknown causes and factors that are difficult to predict and foresee. They occur spontaneously and often have psychological, ergonomic, physiological or other characters. Mostly, these causes make an inessential effect on the selection of teaching methods, but as they build up, their influence becomes so significant that they can make a dramatic change to the prognostic conclusions. The task of pedagogy is to define the training methods from a variety of known (provided) methods, as well as the random (unexpected) causes and factors which in specific context would provide the highest efficiency and productivity of learning.

As a rule, random causes are difficult to predict, and since in different combinations they give completely different results, it is impossible to avoid using computational approaches and computer algorithms.

It is necessary to choose such teaching method selection algorithms that would take into account the probabilistic character of changing parameters (factors and causes), and, on the other hand, would consistently provide high efficiency of these methods.

Today, we know a large number of algorithms for process optimization in the best solution-seeking. But since many of them either limit the initial conditions, the stationary flow of the process, or do not take into account the probabilistic character of the factors influencing the efficient choice, it was decided to use the so-called ant colony algorithms.

It satisfies the multifactor analysis conditions and matches the randomly varying dynamic systems of factors and causes.

\section{Research results}

Tools and procedures. Let us give an example of implementing a «mechanism» for solving a particular pedagogical problem based on the collective pedagogical mind ideas. To describe the main principles of the collective intelligence algorithm, the domain of natural computing has been chosen. Natural computing combines mathematical methods based on the principles of natural decision-making mechanisms and the ant colony algorithms in particular.

We can assume, that there is a hierarchical system of factors that influence the teaching method selection. We can therefore use a table of previously studied factors (Table 1) offered by I. P. Podlasyi (Podlasyi, 2002: 508).

In actual pedagogical practice, there are a great number of such factors, but they do not make a major influence on the problem solution; it was decided therefore to leave the original table unchanged.

A very reputable scientist in the field of pedagogical diagnostics, I.P. Podlasyi lists 
only six general conditions that determine the teaching method choice (Podlasyi, 2002: 508):

1. The regularities and principles of education that arise from them (0.84).

2. The Content and the methods of certain science in general and the subject in particular (0.8).

3. Aims and objectives of education (0.9).

4. Training abilities of the learner (level of training, features of students' group) (0.7).

5. Environmental conditions (ergonomics, production environment, etc.) (0.5).

6. Abilities of the teacher (experience, level of training, knowledge of typical situations of the learning process) (0.35).

Relying on the conditions below, we can plot a table of the factors proximity influencing the method selection. If we formulate it as a hexagonal graph, between its peaks we will see the formation of compounds in the form of lines of factors interacting with each other. We need to choose the most significant peaks (conditions), which in graph theory means that you need to go through all the vertexes of the hexagon, visiting each of them only once, and return to the first vertex. In mathematics, this problem is called the problem of W. Hamilton, a simplified version of the travelling salesman problem. We should use the so-called ant colony algorithm developed by Dr. M. Dorigo to solve this problem (Bonavear \& Dorigo, 1999; Dorigo, 2001).

In nature, everything is very reasonably organized. To confirm it, let us look at the collective interaction of individuals in an ant colony, which represents an «intellectual colony». For over 100 million years of their existence, the ants have fulfilled their algorithm of «intelligent» behaviour and brought it to perfection.

The ants' collective behaviour is based on self-organization, i. e. a set of dynamic mechanisms for achieving a global goal of the system due to low-level interaction between its elements. The principal feature of this interaction is that the elements of the system (agent ants) use only local information (Shtovba, 2004). They find their way using only two points: distance and amount of identifying substance the ants use to mark their routes. This

Table 1. The hierarchy of the factors influencing the method selection

\begin{tabular}{lcc}
\hline \multicolumn{1}{c}{ Factor } & Factor influence & Position \\
\hline Purpose of education. Level of education to be achieved & 0.90 & 1 \\
Level of motivation for education & 0.86 & 2 \\
Implementation of principles, education regularities & 0.84 & 3 \\
Content and requirements to be implemented & 0.80 & 4 \\
Quantity and complexity of training material & 0.78 & 5 \\
Competence of learners & 0.70 & 6 \\
Learners' activity and motivation & 0.65 & 7 \\
Learners' efficiency & 0.62 & 8 \\
Learners' educational skills. Learners' training and endurance level & 0.60 & 9 \\
Duration of training & 0.55 & 10 \\
Facilities and equipment, conditions of education & 0.50 & 11 \\
Application of methods on the previous classes & 0.40 & 12 \\
Type and structure of the class & 0.38 & 13 \\
Relationship between the teacher and learners & 0.37 & 14 \\
developed in the process of studies & 0.36 & 15 \\
Number of learners in a group (class) & 0.35 & 16 \\
\hline Teachers' training level &
\end{tabular}


substance is called pheromone; it is secreted on the tips of the insect's feet, it is quite resistant and can be perceived by ants for several days. The higher the concentration of the pheromone on the route, the more other ants will follow it. Eventually, the pheromone evaporates, allowing ants to adjust their behaviour to the changes in the external environment.

M. Dorigo derived a formula to express the probability of ant's movement $\left(P_{i j}\right)$ from $i$ to $j$ (in graph theory: from one vertex of the graph to the other), which looks as follows:

$$
P_{i j}=\frac{\eta_{i j *}^{\beta} \tau_{i j}^{\alpha}}{\sum_{k} \eta_{i j}^{\beta} * \tau_{i j}^{\alpha}} * 100
$$

where the value $\eta_{i j}^{\beta}$ is the reciprocal of the ant movement distance $\eta_{i j}^{\beta}=\frac{1}{L_{i j}}$ ), and the value $\tau_{i j}^{\alpha}$ is the amount of pheromone on the route. The $\alpha$ and $\beta$ exponents are certain controlled parameters defined accordingly to the weight of the pheromone trail and visibility while choosing a route. The more of these parameters are in any optimization algorithm, the easier it is to adapt it to different situations.

The denominator is the sum the of products value $\sum_{k} \eta_{i j}^{\beta} * \tau_{i j}^{\alpha}$, which forms the numerator to one. This is the sum of products of the same variables standing in the numerator but related not to any particular movement distance from $i$ to $j$, but to any $k$ graph tops involved in this problem (that is through all vertices $k$ ).

\section{Implementation of the ant colony algorithm in the pedagogical problem}

We place the total number of pedagogical conditions that determine the educational method selection on the vertices of a hexagon. The lines between them denote the so-called factors proximity, or, in other words, the difference between these weights. Then we get a certain graph (see Fig. 1).

The value of factors proximity $L_{i j}$ can be found as the difference of the corresponding transitions of weight values, and values of $\tau$ are selected experimentally (Table 2).

Now we can solve this problem by using specific data from Table 2, taking the first vertex (the first condition) as a reference point.

Assume parameter values $\alpha=1$ and $\beta=1$. Then it is possible to direct the sense of rotation from the $1^{\text {st }}$ vertex (first condition) to the vertices $2,3,4,5,6$. It would be logical to choose the nearest vertex. In this case, it would better to use the so-called greedy algorithm. If it is used, all the previous measurements of teaching method "popularity" become unreasonable, as the index gets the value zero $(\alpha=0)$, and for the corresponding value of the variable $\tau$, it equals to one (since any value at zero degrees is equal to one: $\tau^{0}=1$ ).

Assume parameter values $\beta$ to zero $(\beta=0)$, then we get another extreme case, as we ignore

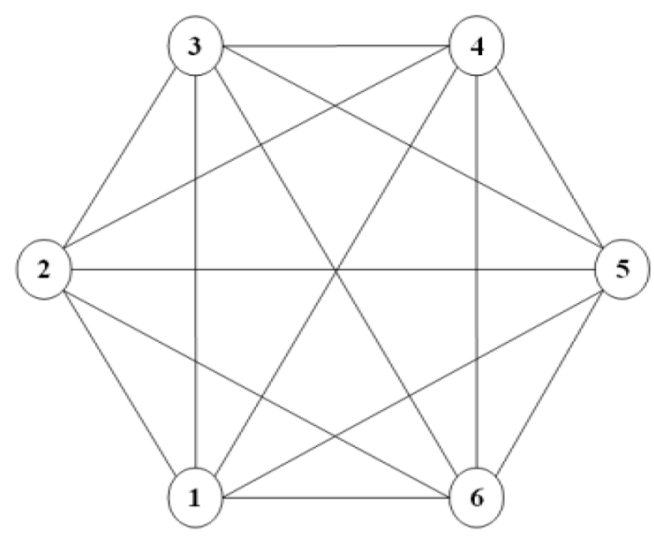

Fig. 1. General conditions that determine the teaching method selection 
Table 2. The proximity of the factors influencing the choice of teaching method

\begin{tabular}{|c|c|c|c|}
\hline Sense of rotation & \multicolumn{2}{|c|}{$\mathrm{L}$} & $\tau$ \\
\hline $1 \rightarrow 2$ & 0.04 & 4 & 2 \\
\hline $1 \rightarrow 3$ & 0.06 & 6 & 3 \\
\hline $1 \rightarrow 4$ & 0.14 & 14 & 2 \\
\hline $1 \rightarrow 5$ & 0.34 & 34 & 1 \\
\hline $1 \rightarrow 6$ & 0.49 & 49 & 1 \\
\hline $2 \rightarrow 3$ & 0.10 & 10 & 3 \\
\hline $2 \rightarrow 4$ & 0.10 & 10 & 3 \\
\hline $2 \rightarrow 5$ & 0.30 & 30 & 1 \\
\hline $2 \rightarrow 6$ & 0.45 & 45 & 1 \\
\hline $3 \rightarrow 4$ & 0.20 & 20 & 4 \\
\hline $3 \rightarrow 5$ & 0.40 & 40 & 2 \\
\hline $3 \rightarrow 6$ & 0.55 & 55 & 2 \\
\hline $4 \rightarrow 5$ & 0.20 & 20 & 2 \\
\hline $4 \rightarrow 6$ & 0.15 & 15 & 2 \\
\hline $5 \rightarrow 6$ & 0.15 & 15 & 1 \\
\hline
\end{tabular}

the range of vertices (factors proximity $L_{i j}$ ), so that the formula does not respond to the visibility of vertices while choosing the route.

What are the specific values of probability, if we start the sense of rotation with the first vertex? Let's calculate.

To do this, we need to substitute the corresponding values from Table 2 (see the first line $1 \rightarrow 2)$ into the formula of M. Dorigo:

$\mathrm{P}_{1,2}=\frac{\frac{1}{4} * 2}{\frac{2}{4}+\frac{3}{6}+\frac{2}{14}+\frac{1}{34}+\frac{1}{49}} * 100=\frac{0,5}{1,19} * 100=42$.

Now substitute the values for the transition $1 \rightarrow 3$ :

$P_{1,3}=\frac{\frac{1}{6} * 3}{\frac{2}{4}+\frac{3}{6}+\frac{2}{14}+\frac{1}{34}+\frac{1}{49}} * 100=\frac{0,5}{1,19} * 100=42$.

Then for the transition $1 \rightarrow 4,1 \rightarrow 5$ and $1 \rightarrow 6$ :

$P_{1,4}=\frac{\frac{1}{14} * 2}{1,19} * 100=\frac{0,14}{1,19} * 100=12$.

$P_{1,5}=\frac{\frac{1}{34} * 1}{1,19} * 100=\frac{0,03}{1,19} * 100=2,4$.
$P_{1,6}=\frac{\frac{1}{49} * 1}{1,19} * 100=\frac{0,02}{1,19} * 100=1,6$.

We have got the set of all probable curves from the $1^{\text {st }}$ vertex to all other possible vertices. It is evident that the greater the factors' proximity (distance between the vertices) $L_{i j}$, the less is the probability that the transition occurs (ants will move there), and the more is the "popularity" of the condition (the number of pheromone values), the higher is the probability of this transition. But in actual pedagogical practice, we can always meet some innovative teachers who behave differently from others. In graph theory, such agents are called elite ants; they chose the way of the greatest probability values, that in our case would be a transition either in vertex 2 or 3 (we have similar transition probabilities in these vertexes and they are equal to $42 \%$ ). The numerical experiment provides an answer to the question of how many extraordinary teachers should be there for a good convergence of the algorithm (Kirsanov, 2007; Shtovba, 2004).

But in actual pedagogical practice, a probabilistic transition to randomly selected vertices is carried out (the so-called eventuality 
among obtained probabilities). For such a random transition we use a random number generator.

Now we should draw a line based on the obtained data. For this purpose, we should lay off the percentage of obtained probabilities on the right line: $42 \%, 42 \%, 12 \%, 2.4 \%, 1.6 \%$ (Fig. 2).

We need to choose the vertex where the arrow pointer gets after rotation. As we can see, eventuality plays a great role here, but it is corrected by reality. In such a way we get to vertex 4, although vertices 2 and 3 would be more preferable, and the chance of choosing between them is similar (42\%).

All the teachers (in the context of the algorithm name -- all ants) and not only the innovative teachers (elite ants) have a chance to make such a random choice and get to vertices 2 or 3 . But according to our calculations, we have got to vertex 4.

From vertex 4 we should complete the rotation to the remaining free vertices $2,3,5$, and 6 (vertex 1 is not allowed as it has already been passed). Once again, the appropriate probabilities need to be calculated. Firstly, transition $4 \rightarrow 2$ :

$P_{4,2}=\frac{\frac{1}{10} * 3}{\frac{3}{10}+\frac{4}{20}+\frac{2}{20}+\frac{2}{15}} * 100=\frac{0,3}{0,73} * 100=40,9$.
Then transition $4 \rightarrow 3$ :

$P_{4,3}=\frac{\frac{1}{20} * 4}{\frac{3}{10}+\frac{4}{20}+\frac{2}{20}+\frac{2}{15}} * 100=\frac{0,2}{0,73} * 100=27,3$.

Then transitions $4 \rightarrow 5$ and $4 \rightarrow 6$ :

$P_{4,5}=\frac{\frac{1}{20} * 2}{0,73} * 100=\frac{0,1}{0,73} * 100=13,6$.

$P_{4,6}=\frac{\frac{1}{15} * 2}{0,73} * 100=\frac{0,13}{0,73} * 100=18,2$.

We draw line of probabilities again: $41 \%$, $27 \%, 14 \%, 18 \%$ (Fig. 3).

Like a roulette, the random number generator selects a certain interval again. For example, it is the sector with vertex 3 (see Fig. 3).

Now, the only possible rotation from this vertex is to vertices 2, 5, and 6 (vertices 1,4 , 3 have already been passed). Once again, we calculate the appropriate probabilities:

$P_{3,2}=\frac{\frac{1}{10} * 3}{\frac{3}{10}+\frac{2}{40}+\frac{2}{55}} * 100=\frac{0,3}{0,71} * 100=42,25$.

$P_{3,5}=\frac{0,05}{0,71} * 100=7,04$.

$P_{3,6}=\frac{0,05}{0,71} * 100=5,12$.

Roulette gets to vertex 5, and the calculated probability:

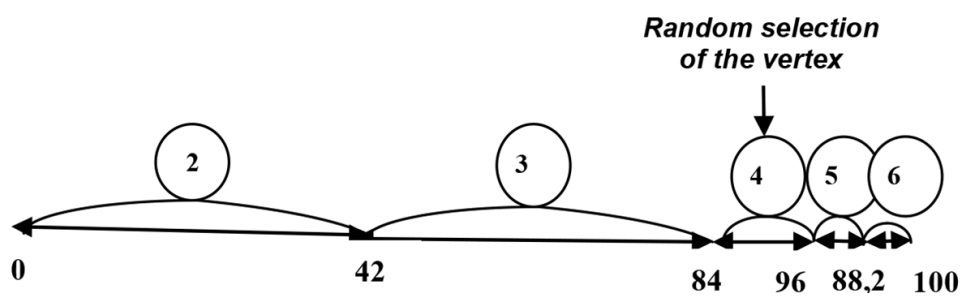

Fig. 2. The line of probabilities of the transitions from the $1^{\text {st }}$ vertex

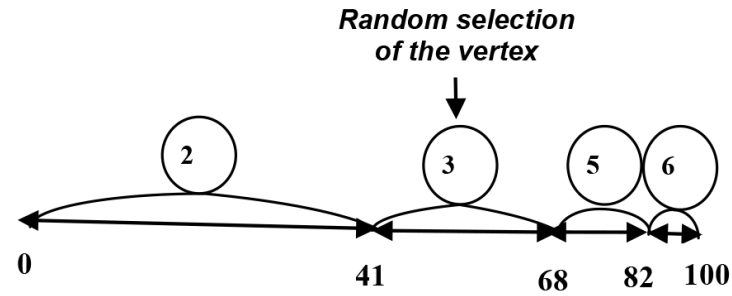

Fig. 3. The line of probabilities of the transitions from the $4^{\text {th }}$ vertex 
$P_{5,2}=\frac{\frac{1}{30} * 3}{\frac{3}{30}+\frac{1}{15}} * 100=\frac{0,1}{0,17} * 100=60,0$.

$$
P_{5,6}=\frac{0,07}{0,17} * 100=40,0 \text {. }
$$

The roulette gets to vertex 6 , and then automatically to the remaining vertex 2 , and finally makes a single transition to the $1^{\text {st }}$ starting position.

We get the final closed rotation route for the first cycle vertices: $1 \rightarrow 4,4 \rightarrow 3,3 \rightarrow 5$, $5 \rightarrow 6,6 \rightarrow 2$ and $2 \rightarrow 1$.

Now you can calculate the entire length of the transition, but the fact is that the longer the distance, the less these routes can be remembered (the fewer pheromones ants can deposit on the path), so a certain total value has been obtained. $L_{k}: \Sigma_{k} L_{k}=L_{0}$. The value $k$ determines the number of summands, in our case, there are 6 of them $(k=6)$.

For the following (second cycle) it is necessary to clarify the value $\Delta \tau$, which strengthens the memory (longevity) of the popularity factor in the teaching method selection (that is, to increase the value of pheromone) in the areas to be reused. This value will be added only to those column dimensions $\tau$ in Table 2, which have already been involved in the rotation, and others will remain with the same values. This value is constant during the entire route, and is calculated with the formula:

$$
\Delta \tau=\frac{Q}{L_{0}} .
$$

The value $Q$ is a constant, and the value $\tau$ should be within the same order as the previous one. This value $\Delta \tau$ is added to the previous value $\tau$, and thereby a new value $\tau^{*}$ is obtained:

$$
\tau_{k j}^{*}=(1-z) * \tau_{k j}+\Delta \tau \text {. }
$$

But this formula is peculiar for forgetting the popularity factor (as the pheromone dries up). An element of forgetting should be presented for the new rotation in the next cycle because the previous version shall not be repeated. This is important, because if the material from the previous cycle is used, the probability of transition to the new route is less, and the new probability may not always be better. This deviation is the positive idea of the ant colony algorithm. It is not essential to use the same cycle, but when the algorithm runs through many vertex search cycles, the finally discovered route becomes statistically significant.

In this formula, the value $z$ is a certain coefficient to be compared to 1 . If its value is increased, the forgetfulness of the used algorithm is also higher. If we take $z=1$, the entire previous history of the vertex rotation gets completely forgotten, and the algorithm remembers only the previous actions at each stage, which is the last cycle. If $z=0$, then the algorithm remembers all the transitions, starting with the first.

When value $\Delta \tau$ has been achieved, a new search cycle starts, but this route is calculated according to the same numbers of factors proximity $L_{i j}$ (column $L$ remains the same in Table 2 ), but the calculation of value $\tau$ should be carried out according to the described formula.

\section{Discussion}

Comparing the total amount of the entire new cycle transition length, it can be possible to get the best, the most significant vertices (conditions) in the form of pedagogical factors which markedly affect the teaching method selection.

The ant colony algorithm has been implemented in Maple software to solve this pedagogical problem (Kirsanov, 2007). Numerous tests have shown that to find the optimal sequence of significant pedagogical conditions, it is necessary to artificially amplify the best current probabilistic solutions by using innovative teachers (elite ants). If there are enough of them (more than 20), then the program finds the optimal solution in 40-50 search cycles, but then the process "goes down" to the local optimum, which is not always the best. By reducing the number of "elite stimulants" to a realistic number (statistics shows that the average number of innovative teachers is one per one thousand), the algorithm starts operating quite slowly, but the result is close to the best solution (100 iterations with 3 elite ants), and the so-called decision traps (false solutions) are carried out more effectively. It is important that the algorithm continues to generate 
better solutions, but does not follow the one that is common to all variants of transition. It coincides with the situation that occurs in actual teaching practice; consequently, the ant colony algorithm is highly effective for finding the best didactic solutions.

Summary. Ant colony algorithm is based on the imitation of social insects self-organization, which is similar to the functioning of social systems in the form of a collective pedagogical megasystem, so it can be efficiently applied for analysis and forecasting of processes and phenomena in pedagogical reality through dynamic mechanisms. Thus, this megasystem reaches global goals "through the local low-level interaction between its element" (Shtovba, 2004).

\section{Conclusions}

The opponents of the "collective educational evolution" concept often criticize it. They point out that it does not focus on the personal interest of a certain agent-educator, and gives an impersonal response, consequently, it does not generate sufficient motivation for professional teachers to work in a team.

We believe that as the human is a reasonable creature, his unconscious collective conclusions are based on the algorithms similar to the ant colony algorithm. And expert decisions, formed on the judgment of the best experts in the corresponding professional field, just complete the overall objective and adjust the decision.

Currently, collective intelligence is needed not only to arrive at the correct pedagogical solutions but to verify the individual's own decisions of ordinary teachers, to correct their teaching activities, to develop self-education, to "support and develop professional compe- tencies for existence in the era of knowledge" (Slavina (ed.), 2014: 291).

External invisible collective intelligence is intended to produce confidence in the trueness of decisions made by an ordinary teacher. It provides support and intellectual assistance, generates the solution of various essential problems in education and development. It is important to note that collective intelligence is not a comprehensive powerful tool, especially in the fields related to the choice of moral priorities, ethical and aesthetic standards, identification of beauty, harmony, and other mental formations, for example, individual emotional intelligence (Ushakov, Liusin (ed.), 2009), sometimes exceeds the strict conclusions of unbiased decisions made with the participation of the collective intelligence. Thus, human intellect becomes both distributed and integrated. It is distributed between the members of the entire collective pedagogical megasystem and integrated as a sum of systemic qualities of individual intellectual activity and the so-called multiple intelligence. Studying multiple intelligence components, $\mathrm{H}$. Gardner notes that "... there is convincing evidence of the existence of several relatively autonomous intellectual abilities, which will be called human intelligences" (Gardner, 2007: 56). Considering linguistic, musical, logical, mathematical, spatial, kinesthetic, intrapersonal and interpersonal intelligence types, he emphasized that "only by expanding and renewing our understanding of human intelligence, we will be able to develop more accurate methods for its diagnostics and more effective means of its development" (Gardner, 2007: 52). It should be also added "and more productive ways of its collective implementation".

\section{References}

Aronson, E. (1998). Obshchestvennoe zhivotnoe. Vvedenie v sotsialnuiu psihologiiu [Social animal. Introduction to social psychology]. Moscow, Aspect Press, $517 \mathrm{p}$.

Bard, A., Zoderkvist, Ya. (2005). NetoKparafl. Novaia praviashchaia elita i zhizn' posle kapitalizma [The new ruling elite and life after capitalism]. St. Petersburg, Stockholm School of Economics, 2005, $252 \mathrm{p}$.

Bonavear, E., Dorigo, M. (1999). Swarm intelligence: from natural to artificial systems, Oxford University Press, 307 p. 
Dorigo, M. (2001). Swarm intelligence, ant algorithms and ant colony optimization. In Reader for CEU Summer University Course «Complex System», Budapest, Central European University, 1-38.

Gardner, H. (2007). Struktura razuma. Teoriia mnozhestvennogo intellekta [Structure of the mind. The theory of multiple intelligences]. Moscow, St. Petersburg, Kiev, Vil'iams, 512 p.

Hardaker, C. (2010). Trolling in asynchronous computer-mediated communication: From user discussions to academic definitions. In Journal of Politeness Research, Language, Behaviour, Culture, (6), 2, $215-242$.

Hebb, D.O. (1949). The Organization of Behavior, NY, Wiley, 60-78.

Heylighen, F. (1996). Vom World Wide Web zum globalen Gehirn. Die Gestaltung eines Nervensystems ffir den neuen Superorganismus. In Telepolis (2), available at: // ttps://www.heise.de/tp/features/VomWorld-Wide-Web-zum-globalen-Gehirn-3445855.html

Janis, I. (1972). Victims of group-think, Houghton Mifflin, 9.

Kirsanov, M. N. (2007). Grafy v Maple. Zadachi, algoritmy, programmy [Graphs in Maple. Tasks, algorithms, programs]. Moscow, FIZMATLIT, $168 \mathrm{p}$.

Podlasyi, I. P. (2002). Pedagogika. Novyi kurs, v 2-kh kn., Kn. 1, Obshchie osnovy. Process obucheniia [Pedagogy. The new course : in 2 v., Vol. 1 , General principles. Learning process]. Moscow, VLADOS, $576 \mathrm{p}$.

Reingold, G. (2006). Umnaia tolpa : novaia sotsialnaia revoliutsiia [Smart crowd : a new social revolution]. Moscow, FAIR-PRESS, $416 \mathrm{p}$.

Rozhdenie kollektivnogo razuma: O novykh zakonakh setevogo sotsiuma i setevoi ekonomiki i ob ikh vliianii na povedenie cheloveka. Velikaia transformatsia tret'ego tysiacheletia [Emergence of collective intelligence: About the new laws of network society and network economy and their impact on human behaviour. The Great Transformation of the third millennium] (2014). Ed. B.B. Slavina, Moscow, LENAND. $288 \mathrm{p}$.

Salminen, J. (2012). Collective Intelligence in Humans - A Literature Review. Submitted 16 April 2012 to: arXiv:1204.3401vl, available at: https://www.researchgate.net/publication/224039929_Collective_Intelligence_in_Humans_A_Literature_Review

Shtovba, S.D. (2004). Murav'inye algoritmy [Ant colony algorithms]. In ExponentaPro. Matematika $v$ prilozheniiakh, (4), 70-75.

Surowiecki, D. (2007). Mudrost' tolpy. Pochemu vmeste my umnee, chem poodinochke, i kak kollektivnyi razum formiruet biznes, ekonomiku, obshchestvo i gosudarstvo [The wisdom of the crowd. Why we are smarter together than alone, and how collective wisdom shapes business, economies, society and the state]. Moscow, Williams, $304 \mathrm{p}$.

Smoll, G. \& Vorgan, G. (2011). Mozg onlain: Chelovek v epokhu Interneta [Online brain: Man in the Internet age]. Moscow, KoLibri. - $352 \mathrm{p}$.

Sotsialnyi i emotsionalnyi intellekt: ot protsessov $k$ izmereniiam [Social and emotional intelligence : from processes to measurements] (2009). Ed. D.V. Ushakov, D.V. Lyusin, Moscow, Institute of Psychology of the Russian Academy of Sciences, $350 \mathrm{p}$.

Sotsialnyi intellekt: Teoriia, izmerenie, issledovaniia [Social intelligence : theory, measurement, research] (2004). Ed. D.V. Ushakov, D.V. Liusin, Moscow, Institute of Psychology of the Russian Academy of Sciences, $176 \mathrm{p}$.

Subbotskii, E.V. (2007). Stroyashcheesia soznanie [Constructing consciousness]. Moscow, Smysl, $424 \mathrm{p}$.

Tapskott, D. (1999). Elektronno-tsifrovoe obshchestvo: Pliusy i minusy epokhi setevogo intellekta [Electronic digital society : advantages and disadvantages of the era of network intelligence]. Kiev, INT Press, Moskva, Reflbuk, 480 p.

Tarasenko, V.V. (2000). Antropologiia Internet: samoorganizatsiia "cheloveka klikaiushchego" [Internet anthropology: self-organization of the Clicking Man]. In Obshchestvennye nauki i sovremennost', (5), $111-120$.

Wellman, B. (2001). Computer networks as social networks. In Science, (293), Issue 5537, 2031-2034. 
Woolley, A.W., Chabris, C.F., Pentland, A., Hashmi, N., Malone, T.W. (2001). Evidence for a collective intelligence factor in the performance of human groups. In Science, (330), 686-688.

Woolley, A.W., Fuchs, E. (2001). Collective intelligence in the organization of the science. In Organization Science, (22), 1359-1367. 